\title{
PERANCANGAN ULANG PRODUK BOTOL TUMBLER DENGAN MEMPERTIMBANGKAN USER EXPERIENCE MENGGUNAKAN METODE GENEVA EMOTION WHEEL (GEW) (Studi Kasus: Starbucks Samarinda)
}

\author{
Amalia Dewi Irawati, Lina Dianati Fathimahhayati, Yudi Sukmono \\ Program Studi Teknik Industri, Fakultas Teknik, Universitas Mulawarman, \\ Jalan Sambaliung No. 9, Kampus Gunung Kelua, Samarinda 75119
}

\begin{abstract}
Abstrak
$\mathrm{B}$ anyaknya produk yang beredar adalah salah satu tantangan besar suatu perusahaan dalam meraih kesuksesan penjualan. Tumbler adalah salah satu barang yang cukup banyak digunakan oleh manusia. Salah satu jenis tumbler yang diminati masyarakat adalah tumbler keluaran salah satu kedai kopi terkenal yaitu Starbucks. Fungsi botol tumbler sendiri sangat membantu dalam kemudahan membawa minuman dan berperan penting terhadap kelestarian lingkungan karena mengurangi penggunaan botol plastik. Permasalahan yang muncul adalah semakin banyaknya ragam tumbleryang ditawarkan dengan banyak pilihan jenis, model, bahan, dan harga sehingga tidak jarang terdapat beberapa jenis tumbler yang kurang diminati dan memiliki tingkat penjualan yang rendah. Pengumpulan data pada penelitian ini dilakukan dengan wawancara, observasi jumlah populasi, pengisian kuesioner Geneva Emotion Wheel (GEW) dan Usability Testing waktu. Kuesioner Geneva Emotion Wheel (GEW) digunakan untuk mengetahui nilai-nilai emosi responden terhadap produk tumbler sebelum dan sesudah product testing serta tumbler hasil perancangan ulang. Kuesioner terdiri dari 10 emosi positif dan 10 emosi negatif yang dirasakan oleh responden. Selain menilai responden juga memberikan alasan dan usulan terhadap produk. Usability Testing dilakukan agar responden dapat berinteraksi dengan produk. Pada penelitian ini dilakukan penilaian tampilan awal produk, product testing, dan penilaian produk setelah product testing. Selanjutnya dilakukan perancangan ulang produk berdasar alasan dan usulan yang telah diberikan dan dinilai kembali oleh responden. Nilai rata-rata awal tampilan tumbler 1 adalah 2,91, sesudah product testing adalah 2,86 dan nilai rancangan ulang produk adalah 3,16. Hal itu disebabkan karena responden puas dengan perubahan volume tumbler yang menjadi lebih banyak dan terdapat tempat untuk whipped cream dan sedotan. Nilai rata-rata awal tampilan tumbler 2 adalah 2,58, sesudah product testing adalah 2,59 dan nilai rancangan ulang produk adalah 3,20. Hal itu disebabkan karena responden menyukai penambahan sedotan yang dapat memudahkan penggunaannya. Nilai rata-rata awal tampilan tumbler 3 adalah 2,20, sesudah product testing adalah 2,21 dan nilai rancangan ulang produk adalah 2,74Nilai rata-rata emosi positif pada masing-masing tumbler mengalami peningkatan setelah dilakukan perancangan ulang.
\end{abstract}

Kata kunci:User Experience, Perancangan Ulang, Tumbler, GEW, Usability.

\section{Pendahuluan}

Banyaknya produk yang beredar adalah salah satu tantangan besar suatu perusahaan dalam meraih kesuksesan penjualan. Persaingan antar perusahaan semakin terlihat dan masing-masing perusahaan berlomba untuk pendapatkan perhatian konsumen. Kreativitas dan ide-ide dituangkan demi dapat menciptakan suatu produk yang dapat mengungguli produk pesaing. Konsumen ditawarkan banyak sekali pilihan produk untuk memenuhi kebutuhan mereka. Saat ini, dalam satu jenis barang terdapat ribuan bahkan jutaan pilihan yang dapat dipilih oleh konsumen.

Botol Tumbler adalah salah satu barang yang cukup banyak digunakan oleh manusia. Salah satu jenis tumbler yang diminati masyarakat adalah tumbler keluaran salah satu kedai kopi terkenal yaitu Starbucks.
Permasalahan yang muncul adalah semakin banyaknya ragam tumbleryang ditawarkan dengan banyak pilihan jenis, model, bahan, dan harga sehingga tidak jarang terdapat beberapa jenis tumbler yang kurang diminati dan memiliki tingkat penjualan yang rendah. Presentase tumbler yang kurang diminati adalah $30 \%$ dari jumlah tumbler 9 buah. Emosi adalah salah satu faktor penting yang dapat mempengaruhi keputusan konsumen dalam menentukan pilihan produk mana yang harus dibeli.

Penilaian reaksi emosional itu penting saat digunakan untuk memahami bagaimana meningkatkan interaksi ketika merancang sebuah produk agar tercipta pengalaman positif konsumen.

Produk yang dapat menimbulkan user experience yang baik pastilah yang akan banyak dipilih oleh konsumen, ada beberapa metode yang bisa digunakan untuk mengukur user experience, salah satunya adalah Geneva Emotion Wheel (GEW). 
GEW mempunyai keunggulan yaitu pilihan emosi yang banyak, memiliki skala 5 poin terlihat cukup untuk mendiferensiasikan intensitas emosi dan rangkaian skala dalam pola melingkar, memberi responden gambaran semua emosi yang dirasakan dan intensitasnya.

Berdasarkan latar belakang masalah maka perlu dilakukan penelitian tentang perancangan ulang produk botol tumbler dengan mempertimbangkan user experience menggunakan metode geneva emotion wheel pada Starbucks Samarinda.

Tujuan yang ingin dicapai pada penelitian ini adalah sebagai berikut:

1. Untuk melakukan penilaian user experience dengan metode GEW dalam proses perancangan ulang produk,

2. Untuk merancang ulang produk yang digunakan dapat meningkatkan user experience berdasarkan hasil penilaian GEW, dan

3. Untuk mengetahui perbandingan waktu yang dihasilkan dari pengujian usability testing waktu pada ketiga tumbler yang diuji berdasarkan product testing.

\section{Tinjauan Pustaka}

a. Ergonomi

Menurut Nurmianto (2004), ergonomi sebagai studi tentang aspek-aspek manusia dalam lingkungan kerjanya yang ditinjau secara anatomi,fisiologi, engineering, manajemen, dan desain atau perancangan, dimana berkenaan dengan optimasi, efisiensi, kesehatan, keselamatan dan kenyamanan manusia ditempat kerja.Secara umum ergonomi adalah ilmu yang mempelajari faktor manusia dalam hubungannya dengan pekerjaan.Tujuan ergonomi adalah terciptanya keseimbangan yang optimum antara manusia, mesin, dan lingkungan.

b. Emosi

Menurut Sacharin, et al. (2012), Emosi merupakan bagian integral dari interaksi dengan orang lain (misalnya, rekan) dan benda-benda seperti barang konsumsi. Penilaian reaksi emosional itu penting saat digunakan untuk memahami bagaimana meningkatkan interaksi ketika merancang sebuah produk agar tercipta pengalaman positif konsumen.

c. Geneva Emotion Wheel (GEW)

Geneva Emotion Wheel merupakan suatu alat pengukuran emosi yang telah diuji secara teoritis maupun emipiris untuk mengukur respon atau reaksi emosi terhadap suatu objek, event maupun situasi.

Berdasarkan Sacharin, et al. dalam Damayanti (2015), Geneva Emotion Wheel membagi emosi menjadi 20 emosi (sepuluh emosi positif dan sepuluh emosi negatif). Emosi-emosi disusun melingkar secara sistematis membentuk roda berdasarkan dua sumbu axis, yaitu valence (negatif dan positif) dan control (high control dan low control). Kedua sumbu tersebut membagi emosi dalam empat kuadran yaitu, negative atau low control, negative atau high control, positive atau high control dan positive atau low control.

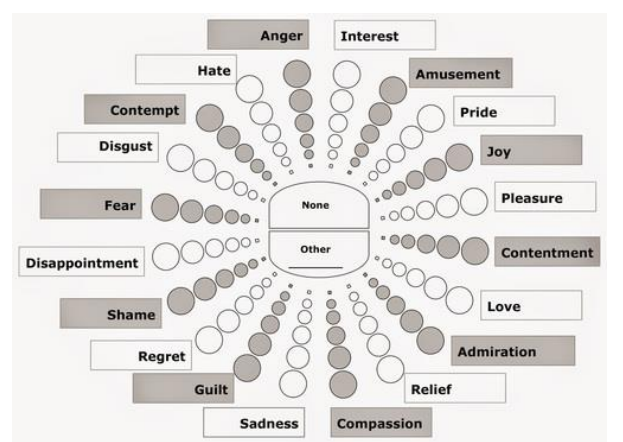

Gambar 1. Geneva Emotional Wheel (GEW)

\section{d. Usability Testing}

Menurut Nielson (1993), usabilitysering didefinisikan sebagai kemudahan untuk mempelajari (learnability), efisiensi penggunaan (efficiency), kemudahan diingat (memorability), sedikit kesalahan (errors), dan kepuasan pengguna (satisfaction).

\section{Metode Penelitian \\ 3.1 Jenis Penelitian}

Penelitian ini termasuk dalam penelitian diskriptif. Penelitian deskriptif adalah salah satu jenis penelitian yang tujuannya untuk menyajikan gambaran lengkap mengenai setting sosial atau dimaksudkan untuk eksplorasi dan klarifikasi mengenai suatu fenomena atau kenyataan sosial, dengan jalan mendeskripsikan sejumlah variabel yang berkenaan dengan masalah dan unit yang diteliti antara fenomena yang diuji.

\subsection{Data Penelitian}

Data primer merupakan data penelitian yang diperoleh secara langsung dari sumber asli, sedangkan data sekunder merupakan data penelitian yang diperoleh secara tidak langsung melalui media perantara. Adapun data yang diperlukan adalah sebagai berikut:

1. Data Primer

Data primer yang dibutuhkan pada penelitian kali ini adalah sebagai berikut:

a. Data produk botol tumbler yang dijual di Starbucks Big Mall Samarinda, dalam penelitian ini digunakan tumbler yang dapat dilihat pada Gambar 3.1 sebagai berikut:

b. Hasil kuesioner Geneva Emotion Wheel sebelum product testing,

c. Hasil kuesioner Geneva Emotion Wheel sesudah product testing, dan

d. Hasil usability testing efisiensi terhadap responden dengan pekerjaan yang harus dilakukan adalah sebagai berikut:

1) Membuka penutup untuk minum,

2) Membuka penutup tumbler, dan

3) Menutup penutup minum. 
2. Data Sekunder

Data sekunder merupakan data yang diperoleh dari literature dan referensi yang berhubungan dengan masalah yang dibahas serta informasi dari buku penunjang literatur dan penelitian terdahulu.

\subsection{Teknik Pengumpulan Data} adalah :

Teknik pengumpulan data yang digunakan

1. Wawancara awal kepada pekerja Starbucks yang mengetahui tentang penjualan tumbler,

2. Observasi dilakukan untuk mengetahui jumlah populasi pengguna tumbler Starbucks.

3. Kuesioner Geneva Emotion Wheel (GEW) yang diberikan pada responden yang merupakan konsumen Starbucks pengguna tumbler sejumlah 47 orang, dan

\subsection{Tahapan Penelitian}

Tahapan penelitian adalah serangkaian langkahlangkah yang akan dilalui dalam melakukan penelitian. Tahapan penelitian terdiri dari 5 tahapan yaitu tahap persiapan, tahap pengumpulan data, tahap pengolahan data, tahap analisis dan pembahasan, dan tahap penutup.

\subsubsection{Tahap Persiapan}

Tahapan persiapan dilakukan analisis awal berdasar desain-desain produk guna mengidentifikasi masalah yang ada. Setelah itu dilakukan studi pustaka untuk mendukung penelitian yang terkait dengan permasalahan sekitar khususnya dalam penyelesaian topik penelitian yang diangkat yaitu dengan menggunakan metode Geneva Emotion Wheel (GEW). Langkah selanjutnya yaitu menentukan tujuan penelitian sebagai hasil akhir yang diharapkan dalam penelitian, lalu menetapkan batasan sehingga penelitian lebih terfokus pada tujuan yang telah disusun sebelumnya.

\subsubsection{Tahap Pengumpulan Data}

Tahapan ini dilakukan pengumpulan data primer dan data sekunder. Pengumpulan data dilakukan di Starbucks Coffee Big Mall, Samarinda, Kalimantan Timur.Penelitian dilaksanakan dalam kurun waktu kurang lebih satu bulan yaitu pada tanggal 5 Desember 2016 sampai dengan 15Januari 2017. Data penelitian ini merupakan hasil kuesioner GEW sebelum dan sesudah product testing dari responden yang selanjutnya dilakukan uji usability testing waktu pengerjaan tugas-tugas yang diberikan.

\subsubsection{Tahap Pengolahan Data}

Tahapan ini dilakukan pengolahan data-data yang telah dikumpulkan sebelumnya. Pengolahan data bertujuan untuk mengetahui hasil penelitian yang dilakukan dan sebagai bahan dalam melakukan analisis lebih lanjut. Adapun pengolahan data yang dilakukan pada penelitian ini adalah sebagai berikut:
1. Evaluasi produk awal dengan menggunakan Geneva Emotion Wheel (GEW),

2. Melakukan product testing dengan menggunakan usabillity testing,

3. Evaluasi produk setelah product testing dengan menggunakan Geneva Emotion Wheel (GEW),

4. Melakukan uji kecukupan data,

5. Melakukan uji normalitas,

6. Melakukan uji signifikansi,

7. Perancangan ulang produk, dan

8. Evaluasi produk rancangan.

\subsubsection{Tahap Analisis dan Pembahasan}

Tahapan ini dilakukan analisis dan pembahasan terhadap hasil pengolahan data yang dilakukan. Adapun tahapan analisis dan pembahasan yang dilakukan adalah sebagai berikut:

1. Menganalisa produk awal berdasarkan respon konsumen yang telah diberikan dengan menghitung skala pada kuesioner Geneva Emotion Wheel (GEW),

2. Menganalisa produk setelah dilakukan product testing berdasarkan respon konsumen yang telah diberikan dengan menghitung skala pada kuesioner Geneva Emotion Wheel (GEW),

3. Menganalisa hasil usabillity testing dari segi waktu pengerjaan tugas-tugas yang diberikan dan dapat dilihat apakah produk mudah digunakan oleh konsumen,

4. Menganalisa uji kecukupan data untuk mengetahui apakah data yang dimiliki sudah cukup digunakan dalam penelitian,

5. Menganalisa uji statistik yaitu uji normalitas untuk mengetahui apakah data berdistribusi normal,

6. Menganalisa hasil uji statistik yaitu uji signifikansi untuk mengetahui apakah terdapat perbedaan yang signifikan antara hasil GEW sebelum dan sesudah product testing,

7. Melakukan pembaruan desain yang dapat meningkatkan user experience dengan melihat hasil kuesioner Geneva Emotion Wheel (GEW) sebagai dasar acuan perancangan ulang produk, dan

8. Menganalisa produk baru yang telah dirancang berdasarkan respon konsumen yang telah diberikan dengan menghitung skala pada kuesioner Geneva Emotion Wheel (GEW). Pada tahapan ini tidak dilakukan pengukuran usabillity testing.

\subsubsection{Tahap Penutup}

Dari hasil analisis data yang dilakukan akan diperoleh kesimpulan berdasarkan latar belakang permasalahan dan tujuan penelitian yang harus dicapai. Berdasarkan kesimpulan, maka diuraikan saran yang relevan terhadap permasalahan yang dihadapi guna memperbaiki dan mengurangi resiko kerja yang terjadi. 


\section{Analisa Dan Pembahasan}

Tumbler Starbucks merupakan salah satu produk unggulan kedai kopi tersebut. Berbagai desain yang ditawarkan sangat diminati oleh para konsumen. Terlebih lagi dengan memberikan penawaran spesial berupa potongan harga minuman setiap membeli dengan menggunakan tumbler. Penawaran lain yang diberikan adalah potongan harga $50 \%$ pada saat tumbler day yaitu pada tanggal 22 setiap bulannya. Tumbler Starbucks juga memiliki keunikan yaitu dengan berganti-ganti tema disesuaikan dengan musim-musim tertentu.

\subsection{Jenis Tumbler dan Karakteristik Responden}

Berdasarkan hasil dari wawancara yang telah dilakukan pada 23 November 2016 kepada pihak Starbucks Big Mall Samarinda, terpilih tiga jenis tumbler yang akan digunakan pada penelitian ini. Ketiga jenis tumbler dipilih berdasarkan tingkat penjualan pada Starbucks Big Mall Samarinda. Tumbler terpilih merupakan model tumbler yang kurang diminati oleh pembeli. Berikut adalah beberapa contoh tumbler lain yang merupakan jenis tumbler yang cukup diminati oleh pelanggan dapat dilihat pada Gambar 4.1:

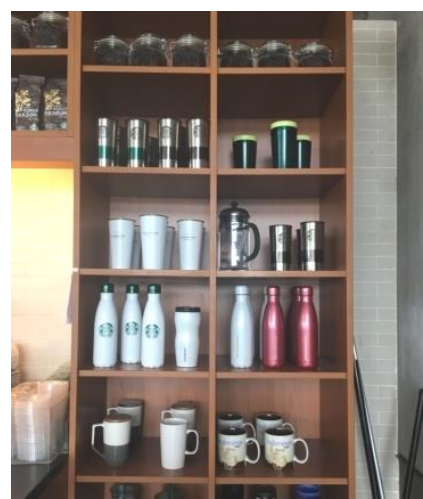

Gambar 2. Jenis tumbler lain yang dipasarkan

Responden yang terlibat pada penelitian ini terdiri dari 28 responden laki-laki dan 17 responden perempuan. Usia responden terdiri dari usia 17 tahun hingga usia 41 tahun. Responden merupakan pengunjung Starbucks Samarinda yang menggunakan tumbler.

\subsection{Sampel Minimal}

Untuk mengetahui jumlah responden, sebelumnya ditentukan popolasi pada penelitian ini yaitu jumlah pembeli pada saat tumbler day pada Starbucks Big Mall Samarinda. Berdasarkan wawancara yang telah dilakukan diperoleh jumlah pembeli saat tumbler day 54 orang.

Diperoleh jumlah sampel minimal yang harus dilakukan dalam penelitian ini dengan menggunakan rumus slovin sejumlah 47 sampel sehingga kuesioner harus disebar kepada pengguna tumbler Starbucks sejumlah 47 pengguna.

\subsection{Uji Kecukupan Data}

Dilakukan uji kecukupan data yang berfungsi untuk mengetahui apakah data yang diperoleh sudah mencukupi untuk diolah pada penelitian ini. Ditentukan tingkat keyakinan sebesar $95 \%$ dan diperoleh nilai $Z$ tabel yaitu 1,64. Nilai presentase kuesiner layak dengan jumlah kuesioner yang disebar sebanyak 47 dan kuesioner cacat sebanyak 2 kuesioner sehingga jumlah kuesioner yang layak adalah 45 kuesioner. Presentase kelonggaran adalah $5 \%$, sehingga uji kecukupan data dapat dihitung dengan Persamaan 2.2:

$$
\begin{aligned}
\mathrm{N} & =\frac{1,64^{2} \times \frac{47-2}{47} \times\left(1-\frac{47-2}{47}\right)}{0,05^{2}} \\
\mathrm{~N} & =43,832 \text { data } \\
& \approx 44 \text { data }
\end{aligned}
$$

Diperoleh nilai uji kecukupan data adalah sebanyak 44 data sedangkan jumlah kuesioner yang disebar adalah 45 , sehingga 45>44 maka jumlah data sudah mencukupi kebutuhan.

\subsection{Geneva Emotion Wheel}

Dilakukan pengumpulan data dengan menggunakan kuesioner Geneva Emotion Wheel pada responden. Berdasar perhitungan rumus solvin diperoleh jumah sampel minimal adalah 45 sampel. Selanjutnya dilakukan pengisian koesioner Geneva Emotion Wheel kepada ke-45 sampel dan diperoleh hasil rata-rata masing masing emosi dapat dilihat pada Tabel 1:

Tabel 1. Rata-rata masing-masing emosi GEW

\begin{tabular}{|l|c|c|c|c|c|c|c|c|c|c|}
\hline & $\mathbf{1}$ & $\mathbf{2}$ & $\mathbf{3}$ & $\mathbf{4}$ & $\mathbf{5}$ & $\mathbf{6}$ & $\mathbf{7}$ & $\mathbf{8}$ & $\mathbf{9}$ & $\mathbf{1 0}$ \\
\hline Tumbler $\mathbf{1} 2,78$ & 2,96 & 2,93 & 2,89 & 3,11 & 2,98 & 2,91 & 3,20 & 2,69 & 2,62 \\
\hline Tumbler $\mathbf{2} 2,67$ & 2,53 & 2,40 & 2,53 & 2,38 & 2,38 & 3,07 & 2,84 & 2,98 & 2,00 \\
\hline Tumbler $\mathbf{3}$ & $\mathbf{1}, 69$ & 2,09 & 2,11 & 2,00 & 2,11 & 2,53 & 2,38 & 2,42 & 2,33 & 2,3 \\
\hline
\end{tabular}

\begin{tabular}{|l|c|c|c|c|c|c|c|c|c|c|}
\hline & $\mathbf{1 1}$ & $\mathbf{1 2}$ & $\mathbf{1 3}$ & $\mathbf{1 4}$ & $\mathbf{1 5}$ & $\mathbf{1 6}$ & $\mathbf{1 7}$ & $\mathbf{1 8}$ & $\mathbf{1 9}$ & $\mathbf{2 0}$ \\
\hline Tumbler 1 2,71 & 3,11 & 3,62 & 2,51 & 3,40 & 2,67 & 2,29 & 2,91 & 2,3 & 2,38 \\
\hline Tumbler 2 22,98 & 3,00 & 2,98 & 1,96 & 2,93 & 1,44 & 2,00 & 1,58 & 1,7 & 2,07 \\
\hline Tumbler 3 & 3,09 & 3,02 & 2,96 & 2,02 & 3,40 & 2,38 & 2,18 & 1,96 & 2,96 & 2,00 \\
\hline
\end{tabular}

Tahap selanjutnya adalah melalukan product testing kepada responden untuk mengetahui apakah ada perbedaan antara hasil emotional pada tampilan awal produk dengan respon dari responden setelah menggunakan produk tersebut. Product testing yang dilakukan sesuai tugas-tugas yang diberikan yaitu membuka penutup untuk minum, membuka penutup tumbler dan menutup penutup minuman.

Selanjutnya digunakan diagram spider web untuk kemudahan pemetaan pada ketiga tumbler seperti pada Gambar 3 dan 4 sebagai berikut: 


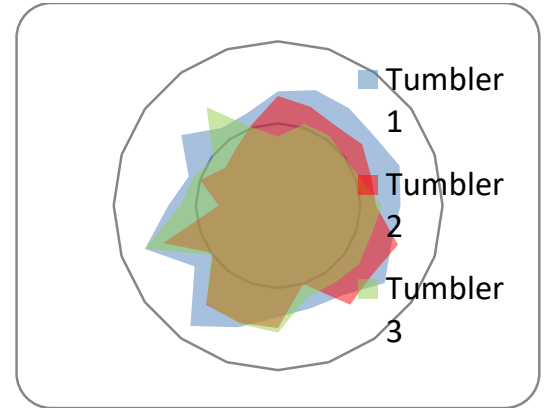

Gambar 3.Sebelum product testing

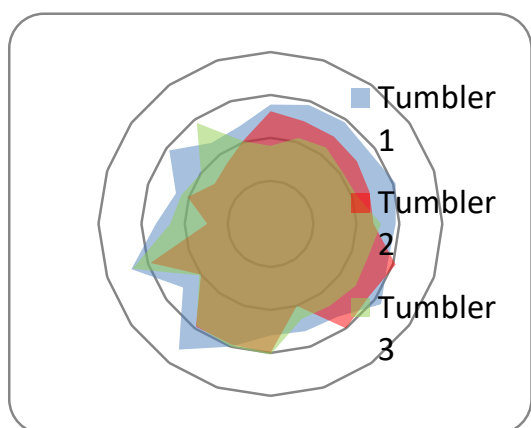

Gambar 4.Sesudahproduct testing

\subsection{Uji Normalitas}

Uji Normalitas dilakukan untuk mengetahui apakah data yang diperoleh berdistribusi normal atau tidak. Selanjutnya dapat digunakan untuk menentukan metode apa yang dapat digunakan untuk melakukan uji signifikansi terhadap hasil kuesioner sebelum dan sesudah product testing.

Hasil output uji normalitas yang telah diperoleh menunjukkan semua data berdistribusi normal karena memiliki nilai asymp.sig $>0,05$. Selanjutnya dilakukan uji signifikansi untuk mengetahui apakah terdapat perbedaan yang signifikan antara rata-rata skor GEW sebelum dan sesudah product testing pada masing-masing tumbler.

\subsection{Uji Signifikansi}

Metode yang digunakan pada uji signifikansi ini adalah uji paired $T$ test. Paired $T$ test merupakan uji beda dua sampel berpasangan. Sampel berpasangan merupakan subjek yang sama namun mengalami perlakuan yang berbeda.

Berdasarkan output uji signifikansi dapat disimpulkan bahwa ternyata tidak terdapat perbedaan yang signifikan pada produk tumbler sebelum dan sesudah product testing. Bila dilihat pada masingmasing produk terdapat perbedaan secara signifikan pada tumbler 1.Hal ini disebabkan karena responden mengalami kesulitan saat membuka penutup tumbler sehingga hasil skor setelah product testing lebih rendah dibanding sebelum product testing.

\subsection{Perancangan Ulang Produk}

Tahapan selanjutnya yang dilakukan adalah perancangan ulang produk yang bertujuan untuk meningkatkan nilai user experience pada produk tumbler.Perancangan ulang mengacu pada penilaian responden yang telah dilakukan.Selain menilai dengan menggunakan GEW tersebut, responden juga diminta mengemukakan alasan kenapa memberikan nilai-nilai emosi pada level tersebut.Berdasarkan alasan tersebut, maka dibuatlah rancangan untuk meningkatkan nilai GEW yang positif sehingga dapat meningkatkan nilai user experience pada produk tumbler.

Bedasarkan penilaian responden terhadap masing-masing tumbler dapat dilihat usulan-usulan perbaikan yang dapat dilakukan adalah:

\section{Tumbler 1}

Berikut adalah usulan-usulan perbaikan yang dapat dilakukan untuk melakukan perancangan ulang pada tumbler 1 :
a. Meningkatkan volume tumbler,
b. Mempertahankan bentuk yang unik,
c. Membuat tempat whipped cream, dan
d. Menambah straw untuk kemudahan penggunaan.

2. Tumbler 2

Berikut adalah usulan-usulan perbaikan yang dapat dilakukan untuk melakukan perancangan ulang pada tumbler 2:
a. Mempertahankan simbol,
b. Menambahkan desain yang lebih menarik, dan
c. Menambah straw untuk kemudahan penggunaan.

3. Tumbler 3

Berikut adalah usulan-usulan perbaikan yang dapat dilakukan untuk melakukan perancangan ulang pada tumbler 3:

a. Memiliki konsep klasik dari Starbucks,

b. Mengganti jenis penutup, dan

c. Menambah straw untuk kemudahan penggunaan.

Sesuai dengan usulan-usulan yang telah diberikan oleh responden, berikut adalah hasil rancangan yang diperoleh yang dapat dilihat:

\section{Tumbler 1}

Perancangan ulang produk berdasarkan pada ulusan-usulan dari responden pada tumbler 1 dapat dilihat pada Gambar 5:

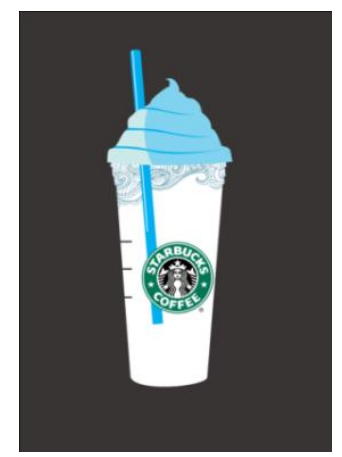

Gambar 5. Perancangan ulang tumbler 1 
Desain rancangan ulang pada tumbler 1 dibuat memiliki volume yang lebih besar dengan menghilangkan bagian mainan dengan mengganti sebagai tempat minuman. Keunikan tumbler diberikan dengan memberi tambahan penutup berbentuk ice cream yang dapat digunakan sebagai tempat whipped cream. Selanjutnya diberi tambahan sedotan untuk mempermudah meminumnya.

\section{Tumbler 2}

Perancangan ulang produk berdasarkan pada ulusan-usulan dari responden pada tumbler 2 dapat dilihat pada Gambar 6:

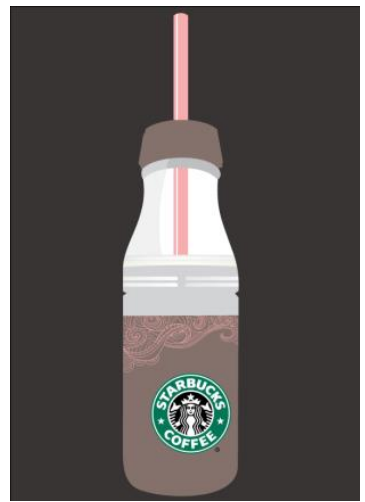

Gambar 6. Perancangan ulang tumbler 2

Desain rancangan ulang pada tumbler 2 dibuat dengan tetap mempertahankan desain botol klasik yang digemari responden. Logo Starbucks tetap diberikan karena logo tersebut merupakan salah satu faktor yang dapat menarik minat pembeli. Diberikan motif sederhana yang menambah keindahan dan penggantian warna agar botol tidak monotone. Penambahan sedotan diberikan untuk kemudahan dalam meminumnya.

\section{Tumbler 3}

Perancangan ulang produk berdasarkan pada ulusan-usulan dari responden pada tumbler 2 dapat dilihat pada Gambar 7:

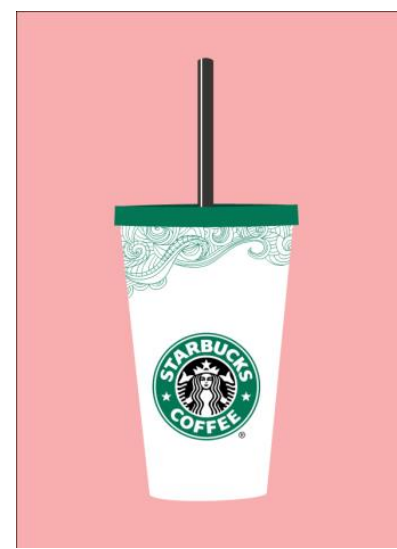

Gambar 7.Perancangan ulang tumbler 3
Desain rancangan ulang pada tumbler 3 dibuat dengan tetap mempertahankan desain botol klasik yang digemari responden. Logo Starbucks tetap diberikan karena logo tersebut merupakan salah satu faktor yang dapat menarik minat pembeli. Diberikan motif sederhana yang menambah keindahan dan penggantian warna agar botol tidak monotone. Warna tutup diserasikan dengan warna logo. Penambahan sedotan diberikan untuk kemudahan dalam meminum.

\subsection{Penilaian GEW Produk Rancangan}

Setelah diperoleh rancangan ulang yang baru berdasarkan usulan-usulan renponden, langkah terakhir pada penelitian adalah melakukan pengukuran nilai emosi GEW pada responden yang sama dan selanjutnya diperoleh nilai rata-rata masing-masing emosi GEW.

Tabel 2.Hasil penilaian GEW rancangan ulang

\begin{tabular}{|r|c|c|c|c|c|c|}
\hline & \multicolumn{2}{|c|}{ Tumbler l } & \multicolumn{2}{c|}{ Tumbler 2 } & \multicolumn{2}{c|}{ Tumbler 3 } \\
\hline & Awal & Rancanngan & Awal & Rancanngan & Awal & Rancanngan \\
\hline Positif & 2,91 & 3,16 & 2,58 & 3,2 & 2,20 & 2,74 \\
\hline Negatif & $-2,79$ & $-2,18$ & $-2,27$ & $-1,92$ & $-2,6$ & $-2,25$ \\
\hline
\end{tabular}

Diperoleh nilai hasil rata-rata GEW produk tumbler yang telah dirancang ulang berdasarkan usulan-usulan yang diberikan oleh responden.Nilai menunjukkan emosi positif yang meningkat dibandingkan dengan tumbler awal. Nilai rata-rata awal tampilan tumbler 1 adalah 2,91, sesudah product testing adalah 2,86 dan nilai rancangan ulang produk adalah 3,16 . Hal itu disebabkan karena responden puas dengan perubahan volume tumbler yang menjadi lebih banyak dan terdapat tempat untuk whipped cream dan sedotan. Nilai rata-rata awal tampilan tumbler 2 adalah 2,58, sesudah product testing adalah 2,59 dan nilai rancangan ulang produk adalah 3,20. Hal itu disebabkan karena responden menyukai penambahan sedotan yang dapat memudahkan penggunaannya. Nilai rata-rata awal tampilan tumbler 3 adalah 2,20, sesudah product testing adalah 2,21 dan nilai rancangan ulang produk adalah 2,74. Hal itu disebabkan karena responden menyukai penambahan sedotan yang dapat memudahkan penggunaannya.Nilai rata-rata emosi positif pada masing-masing tumbler mengalami peningkatan setelah dilakukan perancangan ulang.

\subsection{Perbandingan Hasil Usability Testing}

Berdasarkan penelitian yang telah dilakukan, selanjutnya adalah melihat perbandingan hasil dari usability testing waktu pengerjaan tugas-tugas yang telah diberikan.Adapun tugas-tugas yang telah diberikan adalah membuka penutup untuk minum, membuka penutup tumbler dan menutup penutup minuman. Berikut adalah perbandingan rata-rata waktu yang diperoleh dari responden pada masingmasing tumbler pada: 
Tabel 3.Perbandingan waktu pada ketiga tumbler

\begin{tabular}{|c|c|c|}
\hline \multicolumn{2}{|c|}{ Tugas } & Waktu (detik) \\
\hline \multirow{3}{*}{1} & Tumbler 1 & 3,60 \\
\cline { 2 - 3 } & Tumbler 2 & 2,57 \\
\cline { 2 - 3 } & Tumbler 3 & 2,19 \\
\hline \multirow{3}{*}{2} & Tumbler 1 & 4,09 \\
\cline { 2 - 3 } & Tumbler 2 & 3,17 \\
\cline { 2 - 3 } & Tumbler 3 & 1,81 \\
\hline \multirow{3}{*}{3} & Tumbler 1 & 3,79 \\
\cline { 2 - 3 } & Tumbler 2 & 3,13 \\
\cline { 2 - 3 } & Tumbler 3 & 1,74 \\
\hline
\end{tabular}

Berdsarkan pada tabel di atas dapat dilihat perbandingan rata-rata waktu yang dihasilkan dari product testing oleh responden. Angka 1 hingga 3 menunjukkan urutan tugas-tugas yang diberikan. Tugas ke-1 adalah membuka penutup untuk minum, tugas ke-2 adalah membuka penutup tumbler dan tugas ke-3 adalah menutup penutup minuman.

\section{Kesimpulan}

1. Penilaian GEW untuk mengukur user experience pada tumbler harus dilakukan pada tampilan dan fungsi produk. Penilian GEW dapat mewakili user experience dari gambaran emosi pengguna yang muncul saat melihat dan berinteraksi dengan produk. Diperoleh penilaian yang tidak berbeda secara signifikan antara emosi saat hanya melihat dan berinteraksi dengan produk. Perbedaan hasil penilaian GEW pada tampilan dan fungsi produk dapat digunakan menarik kesimpulan untuk pengembangan produk yang dapat meningkatkan user experience. Diperoleh nilai user experience yang meningkat antara desain awal dan hasil desain ulang.

2. Setelah dilakukan perancangan ulang produk, diperoleh nilai emosi GEW meningkat dari produk tumbler awal. Hal ini menunjukkan bahwa upaya peningkatan user experience dapat dilakukan dengan perancangan ulang berdasar usulan-usulan responden. Usulan yang diberikan pada tumbler 1 adalah meningkatkan volume tumbler, mempertahankan bentuk yang unik, membuat tempat whipped cream, dan menambah straw untuk kemudahan penggunaan. Usulan yang diberikan pada tumbler 2 adalah mempertahankan simbol, menambahkan desain yang lebih menarik, dan menambah straw untuk kemudahan penggunaan. Usulan yang diberikan pada tumbler 3 adalah memiliki konsep klasik dari Starbucks, mengganti jenis penutup, dan menambah straw untuk kemudahan penggunaan.

3. Hasil usability testing waktu menunjukkan tumbler 3 memiliki waktu penggunaan tercepat karena kemudahan membuka penutup untuk minum, membuka penutup tumbler dan menutup penutup minuman.

\section{Daftar pustaka}

Azwar, S. (2005). Signifikan atau Sangat Signifikan, Jurnal Psikologi UGM, vol. 13 No. 1, Universitas Gajah Mada, Yogyakarta.

Damayanti, K. A., Martaleo, M., Gunawan, C. E. (2015).Perancangan Ulang Produk Dengan Mempertimbangkan User ExperienceMenggunakan Metode Geneva Emotion Wheel, Proceeding Seminar Nasional Perhimpunan Ergonomi Indonesia, Universitas Katholik Parahyangan, Bandung.

Gumulya, D. dan Natasia, P.(2015).Kajian Teori Emotional Design, Jurnal Desain, vol. 3 No. 1, Universitas Pelita Harapan, Tangerang.

Nielsen, J.(1993).Usabillity Engineering, Sun Soft, California.

Nurhayati (2008). Studi Perbandingan Metode Sampling antara Simple Random dengan Stratified Random, Jurnal Basis Data ICT Research Center, vol.3 No.1, UNAS, Jakarta.

Nurizzati, Y.(2016) Efektivitas Pembelajaran Statistik Dasar Dengan Metode Praktikum Berbasis Pendidikan Karakter Islami di Jurusan Tadris Ilmu Pengetahuan Sosial Iain Syekh Nurjati Cirebon, Jurnal Holistik, vol. 1 No. 1, IAIN Syekh Nurjati, Cirebon.

Nurmianto, E. (2004)Ergonomi Konsep Dasar dan Aplikasinya, Guna Widya, Surabaya.

Putra, R. (2013) Aplikasi SIG untuk Penentuan Daerah Quick Count Pemilihan Kepala Daerah, Jurnal Geodesi Undip, vol. 2 No. 4, Universitas Diponegoro, Semarang.

Sacharin, V., Schlegel, K., \& Scherer, K. R.(2012)Geneva Emotion Wheel Rating Study (Report), University of Geneva, Switzerland.

Scherer, K. R. (2005)What are emotions? And how can they be measured?, SAGE Publications, London.

Sugiono (2005)Statistika Untuk Penelitian, Alfabeta, Bandung.

Ulrich, K., \&Eppinger, S.(2011).Product Design and Development, McGraw-Hill, New York.

Wignjosoebroto, S. (2006).Analisis Ergonomi Terhadap Rancangan Fasilitas Kerja Pada Stasiun Kerja Dibagian Skiving Dengan Antropometri Orang Indonesia (Studi Kasus Di Pabrik Vulkanisir Ban), Institut Teknologi Sepuluh November, Surabaya.

Wiryawan, M. B. (2011). User Experience (Ux) Sebagai Bagian Dari Pemikiran Desain Dalam Pendidikan Tinggi Desain Komunikasi Visual, Jurnal Humaniora, vol. 2 No. 2, BINUS University, Jakarta. 
e-ISSN : 2621-8933 p-ISSN : 1693-5128

doi:10.30587/matrik.v19i2.715

(Halaman ini sengaja dikosongkan) 